\title{
CORRELATION OF SPECIFIC COORDINATION BY YOUNG FEMALE VOLLEYBALL PLAYERS AND PERFORMANCE LEVEL OF TECHNICAL ELEMENTS IN VOLLEYBALL
}

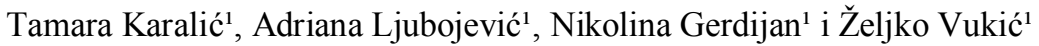 \\ ${ }^{1}$ Faculty of Physical Education and Sports University of Banja Luka, Bosnia and Herzegovina
}

Original scientific paper

\section{SUMMARY}

In a study with transversal character participated 40 female volleyball players, selected by clearly defined critiques. The tests that were conducted are from the domain of specific volleyball coordination (predictors) and the precision of playing a ball with "bump" (criteria). The aim is to examine the relationship of predictors on the criterion variables and on that way create a precondition for predicting the level of precision of the female volleyball players.

The female volleyball players have shown that they coordinating skills are statistically

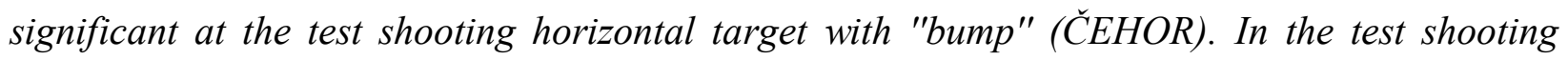
vertical target with "bump" (ČEVER) they showed up two types of coordination, coordination in space and coordination by the volleyball net, while in the third test, shooting horizontal target with "bump" in position 2 (ČEPOZ2), as significant have shown coordination by the volleyball net and one-handed juggling ball through the hoop.

The importance and complexity of coordination in this and similar transversal research is evident, so the conclusion is that there is an relationship specific coordinative abilities with the correct performance of volleyball techniques and that latent factors, who have determined the coordinating ability of the female volleyball players can act independently, but also depend on each other. Without a doubt, without a well coordinated volleyball player, we can not expect efficient performance of the set technical-tactical structures in the volleyball game.

Key words: volleyball, coordination, precision. 


\section{INTRODUCTION}

Volleyball is a sport activity that has a many different movements of the players. It's clear that, to perform these such demanding movments, learning of new movements and for rapid change of one movement with another (Drabik, 1996), coordination is the unavoidable factor for success of one volleyball player. For coordination abilities it says that they are a form of motor intelligence because during the game it participates, more or less, in all the movments and activities (anticipating the ball trajectory, time alignment of the movement to the ball (timing), observation of a player's and opponents' movement, high time pressure during the transition period of defense and attack, feeling for the ball at service reception, blocking, and precise addition, spiking or serving). There is no doubt that its multidimensionality and complexity requires a clear definition of factors, with latent character, which can even be universal for this motor ability. Complexity of this motor skills has been established long time ago. Previous research (Verstegen \& Marcello, 2001; Stein, Simonidis, Seemann \& Schwameder, 2010; Idrizović, 2011; Karamatić, Vuljanić \& Peršun, 2011; Macner, 2011; Njaradi, 2011; Tomljanović, Krespi \& Bešlija, 2011; Vučetić, Sukreški \& Zuber, 2011; Urgesi, Savonitto, Fabbro \& Aglioti, 2012; Milanović, Šalaj \& Gregov, 2012; Yasumitsu \& Nogawa, 2013; Button, Wheat \& Lamb, 2014; Pion, Fransen, Deprez, Segers, Vaeyen, Philippaerts \& Lenoir, 2015; Šimonek, 1998; 2006; 2009; 2014; 2016) largely confirm the assumption that coordination, among other things, implies the precision of performing the task, rhythmicity (performing movable operations precisely at certain spatial and temporal intervals), balance (ability to maintain a stable position in dynamic motion structures), reaction ability, kinesthetic differentiation (use adequate amounts of power for a particular movement), orientation in space (ability to customize one's own body or part of body in space), the economyness of movement as well as the synchronization of movement in time. Therefore, because of the many varied, technically demanding, complicated and untypical movements in volleyball game, we can rightly talk about two key factors for success: specific coordination associated with ball handling skills and special volleyball precision. 
In order to test the correlation of predictive variables of specific coordination ability of the female volleyball players with the level of playing/adding a ball with forearm ${ }^{1}$, as a system of criterion variables, was conducted a research of transversal character.

Based on the results test of specific coordinating abilities, and the results test of the technique playing or adding a ball with forearms, the basic premise is that it will be possible to predict the level of precision of the female volleyball players.

So whatever it is, general, specific or situational coordination, the research has shown the essence of this ability: the proper relationship of established latent factors as parts of the whole, that give effective results.

\section{METHOD}

The sample consisted of 40 female volleyball players. The criteria for the selection of subjects are: (1) Subjects used as a sample were 14 to 16 years of age ( \pm 6 months); (2) that they are active members of the volleyball teams from Republika Srpska; (3) that they actively train volleyball for at least 2 to 4 years; (4) that they actively participate in the realization of the training; (5) that training plan provides load of 5 per week for all subjects, with a duration 1 training 90-120 minutes; (6) that all subjects were underwent to a medical examination and they are healthy. Before starting the measurement, it is verified whether the accuracy of the instrument, and if necessary adjusted. According to the research tasks set, they are secured technical conditions to get the most accurate results. (1) measurement was done during the morning (8 AM to $14 \mathrm{PM}$ ); (2) instruments of standard manufacturing and they were controlled before and after the 10 subjects; (3) the subjects were tested in a sports hall that is sufficiently spacious and illuminated. The temperature is such that the subjects feel comfortable (according to the Rules of volleybal from $16^{\circ}$ to $25^{\circ}$ ); (4) all measurements were performed by two or three measurer, and each of them carried out the same measurements; (5) the subjects were in the sports equipment and (6) the results measurement are read at the end of each task, and a person who registered it for control purposes, loudly was repeated the results before being enrolled in protocol of subjects.

\footnotetext{
${ }^{1}$ Later on in the text it is used the term 'bump".
} 
Tests were selected from previously conducted research (Strahonja, Janković \& Šnajder, 1982;

Strahonja \& Janković, 1988; Marelić, Đurković \& Rešetar, 2007; Karalić, 2010; Stojanović, N.,

Stojanović, T., Stojanović, D., Herodek \& Jurko, 2014).

Motor tests sample - Specific coordination abilities, Independent variables:

\section{One-hand juggling a ball through a hoop (ŽONG)}

The aim: I's measured a skill of shooting a target. Task: A volleyball player stands in volleyball stance below the target, he tosses the ball with one hand, strikes the the fist (or with a taut palm) and trying to shoot the frame of the hoop. When the ball pass through the hoop or around hoop, he trying with the other hand to shoot the frame. Time of test performance is 20 seconds. If the subject accidentally drop a ball, takes another ball and continue the task. Final score: sum of the total number of hits.

\section{Test coordination by the volleyball net (KOOMRE)}

The aim: I's measured a coordination ability of volleyball player. Task: A volleyball player stands in volleyball stance in front of the net. He jumped up and raised his hands to block (in jump raised fists above the upper edge of the net), lands and do collet to the back, on line of attack, he lay on his stomach, with the technique of rolling turned to 360

${ }^{\circ}$ back to stomach, then he turned itself to the net, and jumps to spike to hit the ball with the fist that the assistant keeps over the net. The stopwatch is turned off when the volleyball player hit the ball, that the assistant keeps over the net. Final score: to the achieved time edds by one second for every made mistakes (touch of net in the block, spike, awkwardly coasting and rolling).

\section{Test coordination in space (KOOPRO)}

The aim: I's measured a coordination ability of volleyball player. Task: A volleyball player fit in volleyball stance position in front the left line of the square. Jump 3 times by this line to come to the next line, with three jumps with right and left foot run across the line so that with right foot reflects on the right and with the left foot the left side of the line, and coming to the end of his back turned with 6 jumps of backward came back to the fourth line then with 3 crossed steps pass over the fourth line. Final score: to the achieved time edds by one second for every made mistakes (larger or smaller number of jumps, rough distortion of direction in relation to the line.

\section{Hexagon test (HEKS)}

The aim: I's measured a coordination ability of volleyball player and and agility. Task: A volleyball player stands in volleyball stance in the middle of hexagon. Volleyball player is turned with face toward to the line A, during a skipping over all lines. Then jump out over B, and go back to the middle. So skip all lines in the order C, D, E, F, A. Volleyball player must make three rounds, then the stopwatch stops. Final score: it takes the best time in three attempts. 
Motor tests sample - Precision of plaing balls with "bump", dependent variables:

\section{Shooting the horizontal target with the "bump" (ČEHOR)}

The aim: I's measured a shooting with 'bump" a target that is horizontally placed. Task: A volleyball player stands in volleyball stance upright in relation to the target at a distance of $3 \mathrm{~m}$, takes the ball, tosses them and with 'bump" trying to shoot the middle of the ring. Final score: sum of the total number of points from 10 attempts.

\section{Shooting the target in the horizontal plane from position 2 (ČEPOZ2)}

The aim: I's measured a shooting with 'bump" a target that is horizontally placed in position 2. Task: A volleyball player stands in volleyball stance in position $6,1 \mathrm{~m}$ behind the line of attack. Horizontal target is set in the middle of position $2(1.5 \mathrm{~m}$ from the net and the right side of the lateral line). The feeder is in the middle of position 1 ( $3 \mathrm{~m}$ behind the line of attack, and the right side of the lateral the line). The feeder throws the balls in the direction of receiver who tried that with "bump" shoot the target in position 2. Final score: sum of the total number of points from 10 attempts.

\section{Shooting the vertcal target with "bump" (ČEVER)}

The aim: I's measured a shooting with 'bump" a target that is vertically placed. Task: A volleyball player stands in volleyball stance upright in relation to the target at a distance of $3 \mathrm{~m}$, takes the ball, tosses them and with 'bump" trying to shoot the middle of the ring. Final score: sum of the total number of points from 10 attempts.

In order to determine the nature of relationships and prediction efficiency of shooting horizontal and vertical target with "bump" on the basis of indicators specific coordination in volleyball, a multiple linear regression analysis was applied. From the domain of discriminative analysis, the ANOVA variance analysis was used to check the correlation level (one or more) on the variability of a given phenomenon.

\section{RESULTS}

Table 1. shows the descriptive statistics for a set of dependent and independent variables. According to the present parameter values, distribution of the results for the total sample volleyball players $(n=40)$ is generally in the range of normality, which indicates the homogeneity of the sample of individuals, which provided further processing of data. 
Table 1. Basic statistical parameters for a set of dependent and independent variables

\begin{tabular}{ccccccc}
\hline \multicolumn{7}{c}{ The basic statistical parameters } \\
\hline & $\mathbf{N}$ & Mean & Min. & Max. & Std.Dev. & KS \\
\hline ČEHOR & 40 & 6.85 & 5.00 & 9.00 & 1.10 & 0.18 \\
\hline ČEVER & 40 & 8.28 & 6.00 & 11.00 & 1.18 & 0.21 \\
\hline ČEPOZ2 & 40 & 7.00 & 5.00 & 10.00 & 1.30 & 0.42 \\
\hline ŽONG & 40 & 9.73 & 7.00 & 15.00 & 1.99 & 0.47 \\
\hline KOOMRE & 40 & 7.57 & 6.27 & 8.66 & 0.55 & 0.94 \\
\hline KOOPRO & 40 & 9.54 & 8.92 & 10.70 & 0.42 & 0.52 \\
\hline HEKSA & 40 & 25.18 & 24.12 & 26.71 & 0.51 & 0.55 \\
\hline
\end{tabular}

In table 2 the value of multiple correlation coefficient between the dependent variable Shooting the horizontal target with the "bump" (С̌EHOR) and system variables specific coordinative skills is $\mathbf{R}=\mathbf{0 . 4 6}$ which points to significant correlation between the observed systems. The correlation is also statistically significant at $\mathbf{p}=\mathbf{0 . 0 0 1}$ (Table $2 \mathrm{a}$ ). The results were obtained based on the degrees of freedom $\mathbf{d f _ { 1 }}=\mathbf{2}$ and $\mathbf{d f _ { 2 }}=\mathbf{3 7}$ and limit values for the F-test. For the statistically significant values accepted are those whose (limit) value of F-test was greater or equal to $\mathbf{3 . 2 3}$ at the significance level of $\mathbf{p}=\mathbf{0 . 0 5}$. The resulting value of $\mathbf{R}^{\mathbf{2}}=\mathbf{0 . 1 9 2 9}$ suggests that $19.29 \%$ of the total variability of the results of Shooting the horizontal target with the "bump" (ČEHOR) is determined by the variability of the independent variables system. The rest of $80.71 \%$ is not explained by regression model, so, it's influenced by some other unidentified (latent) factors, probably physiological, anthropomotor or psychological nature.

Table 2. Results of multiple regression analysis for the dependent variable Shooting the horizontal target with the "bump" (ČEHOR)

\begin{tabular}{|c|c|c|c|c|}
\hline Model & Multiple R & Multiple $\mathbf{R}^{2}$ & Adjusted R ${ }^{2}$ & Std.Err. of Estimate \\
\hline 1 & 0.460032 & 0.192915 & 0.129933 & 10.89724 \\
\hline
\end{tabular}


Table 2a. Analysis of variance of the dependent variable Shooting the horizontal target with the "bump" (ČEHOR)

\begin{tabular}{ccccccc}
\hline \multicolumn{2}{c}{$\begin{array}{c}\text { ANOVA } \\
\text { (Effect) }\end{array}$} & SS & df & MS & F & Sig. \\
\hline \multirow{4}{*}{ ČEHOR } & Regresson & 553.78 & 2 & 138.44 & 5.587 & $\mathbf{0 . 0 0 1}$ \\
& Residual & 1239.06 & 37 & 24.78 & & \\
& Total & 1792.84 & 39 & & & \\
\hline
\end{tabular}

$d f 1=2 ; d f 2=37 ; f=3.23 ; P=0.05$

Legend: $S S$ - Sq square; $M S$ - values of regression and residual variance; $D f$-degree of freedom; $F$ - F test; Sig. - realized level of significance;

From the set of variables of specific coordinative abilities (Table 2b) it was shown that the results of test Shooting the horizontal target with the "bump" (ČEHOR), used to estimate precision, can statistically significantly predict $(\mathbf{p}=\mathbf{0 . 0 4 2})$ based on the results of the Test coordination in space (KOOPRO), used for evaluation of coordination, and whose beta coefficient is Beta $=\mathbf{- 0 . 1 9 9}$. The other variables of the specific coordination space have no statistical significance (Table 2b).

Table 2b. Beta Coefficients - Relative effect or importance of each independent variable

\begin{tabular}{ccccccc}
\hline & Beta & Std.Err. - of Beta & B & Std.Err. - of B & t & p-level \\
\hline ŽONG & 0.02 & 0.10 & 0.03 & 0.15 & 0.23 & 0.82 \\
KOMRE & 0.122 & 0.097 & 0.219 & 0.174 & 1.260 & 0.210 \\
KOOPRO & -0.199 & 0.097 & -1.110 & 0.538 & -2.062 & $\mathbf{0 . 0 4 2}$ \\
\hline HEKS & -0.023 & 0.094 & -0.048 & 0.197 & -0.244 & 0.808 \\
\hline
\end{tabular}

Legend: Beta - coefficient of partial regression; Std.Err. - of Beta - standard partial regression coefficient error; Tthe value of the Beta coefficient test; P-level - the significance of the Beta coefficient

In Table 3, the value of the multiple correlation coefficient between the dependent variables Shooting the vertcal target with "bump" (ČEVER) and the system of specific coordinating abilities variables is $\mathbf{R}=\mathbf{0 . 3 7}$ which indicates a somewhat weaker correlation between the observed systems. The correlation is also statistically significant at $\mathbf{p}=\mathbf{0 . 0 0 0}$ (Table $3 \mathrm{a}$ ). The obtained value $\mathbf{R}^{2}=\mathbf{0 . 1 4 8 5}$ indicates that $14.85 \%$ of the total variability of the results Shooting the vertcal target with "bump" (ČEVER) determined variability of the system of independent 
variables. The rest of $85.15 \%$ is not explained by the regression model, so it's under the influence of some other anthropological characteristics or the ability of female volleyball players that are not the subject of this research.

Table 3. Results of multiple regression analysis for the dependent variable Shooting the vertcal target with "bump" (ČEVER)

\begin{tabular}{ccccc}
\hline Model & Multiple R & Multiple R $^{\mathbf{2}}$ & Adjusted R $^{\mathbf{2}}$ & Std.Err. of Estimate \\
\hline $\mathbf{1}$ & 0.372196 & 0.148500 & 0.084814 & 1.736541 \\
\hline
\end{tabular}

Table 3a. Analysis of variance of the dependent variable Shooting the vertcal target with "bump" (ČEVER)

\begin{tabular}{clccccc}
\hline \multicolumn{2}{c}{$\begin{array}{c}\text { ANOVA } \\
\text { (Effect) }\end{array}$} & SS & df & MS & F & Sig. \\
\hline \multirow{3}{*}{ ČEVER } & Regresson & 1433.77 & 2 & 358.44 & 7.743 & $\mathbf{0 . 0 0 0}$ \\
& Residual & 2314.66 & 37 & 46.29 & & \\
& Total & 3748.44 & 39 & & & \\
\hline
\end{tabular}

It has also been shown that the test results of Shooting the vertcal target with "bump" (ČEVER) used to estimate precision, can statistically significantly predict $(\mathbf{p}=\mathbf{0 . 0 0 7}$ and $\mathbf{p}=\mathbf{0 . 0 0 2}$ ), based on the results of the Test coordination in volleyball net (KOOMRE) and Test coordination in space (KOOPRO). This is also confirmed by the Beta coefficient values for the mentioned independent variables $($ Beta $=\mathbf{0 . 2 8 4}$ and Beta $=\mathbf{0 . 2 9 3})$. The other variables of the specific coordination space have no statistical significance (Table $3 b$ ).

Table 3b. Beta Coefficients - Relative effect or importance of each independent variable

\begin{tabular}{ccccccc}
\hline & Beta & Std.Err. - of Beta & B & Std.Err. - of B & t & p-level \\
\hline ŽONG & -0.046 & 0.106 & 0.023 & 0.052 & -0.432 & 0.671 \\
KOMRE & 0.284 & 0.104 & 0.065 & 0.024 & -2.735 & $\mathbf{0 . 0 0 7}$ \\
KOOPRO & 0.293 & 0.105 & 0.068 & 0.022 & -2.633 & $\mathbf{0 . 0 0 2}$ \\
HEKS & 0.013 & 0.105 & 0.000 & 0.002 & 0.098 & 0.922 \\
\hline
\end{tabular}


Table 4. Results of multiple regression analysis for the dependent variable Shooting the target in the horizontal plane from position 2 (ČEPOZ2)

\begin{tabular}{ccccc}
\hline Model & Multiple R & Multiple R & Adjusted R & Std.Err. of Estimate \\
\hline $\mathbf{1}$ & 0.44061 & 0.20244 & 0.135576 & 11.045297 \\
\hline
\end{tabular}

In Table 4, the value of the multiple correlation coefficient between the dependent variables Shooting the target in the horizontal plane from position 2 (ČEPOZ2) and a system of specific coordinating abilities variables is $\mathbf{R}=\mathbf{0 . 4 4}$, which points to the significant correlation of the observed systems. The correlation is also statistically significant at $\mathbf{p}=\mathbf{0 . 0 0 1}$ (Table 4a). The obtained value $\mathbf{R}^{2}=\mathbf{0 . 2 0 2 4}$ points to the conclusion that $20.24 \%$ of the total variability of the result of the Shooting the target in the horizontal plane from position 2 (ČEPOZ2) is determined by the variability of the system of independent variables. The rest of $79.76 \%$ is not explained by the regression model, so it's under the influence of some other anthropological characteristics or the ability of the young female volleyball players.

Table 4a. Analysis of variance of the dependent variable Shooting the target in the horizontal plane from position 2 ( $\breve{C E P O Z 2)}$

\begin{tabular}{ccccccc}
\hline \multicolumn{2}{c}{$\begin{array}{c}\text { ANOVA } \\
\text { (Effect) }\end{array}$} & SS & df & MS & F & Sig. \\
\hline \multirow{4}{*}{ ČEPOZ2 } & Regresson & 553.78 & 2 & 138.44 & 5.587 & $\mathbf{0 . 0 0 1}$ \\
& Residual & 1239.06 & 37 & 24.78 & & \\
& Total & 1792.84 & 39 & & & \\
\hline
\end{tabular}

In Table 4a, it has also been shown that the test results of Shooting the target in the horizontal plane from position 2 (ČEPOZ2) used to estimate precision, can statistically significantly predict $(\mathbf{p}=\mathbf{0 . 0 0 4}$ and $\mathbf{p}=\mathbf{0 . 0 3 1})$ based on the results of the One-hand juggling a ball through a hoop $(\check{Z} \mathrm{ONG})(\mathbf{B e t a}=\mathbf{- 0 . 4 1 0})$ and Test coordination in volleyball net (KOOMRE) $($ Beta $=\mathbf{0 . 2 8 0})$. The other variables of the specific coordination space have no statistical significance. 
Table 4b. Beta Coefficients - Relative effect or importance of each independent variable

\begin{tabular}{ccccccc}
\hline & Beta & Std.Err. - of Beta & B & Std.Err. - of B & t & p-level \\
\hline ŽONG & -0.410 & 0.159 & -0.504 & 0.538 & -3.143 & $\mathbf{0 . 0 0 4}$ \\
KOMRE & 0.280 & 0.164 & 0.368 & 0.455 & 2.257 & $\mathbf{0 . 0 3 1}$ \\
KOOPRO & -0.158 & 0.188 & 0.199 & 0.158 & 0.571 & 0.571 \\
HEKS & 0.254 & 0.169 & 0.294 & 0.176 & 1.743 & 0.091 \\
\hline
\end{tabular}

\section{DISCUSSION}

The basic motor skills as the basis for upgrading specific motor skills through a longstanding volleyball training process are important for success, because they to a large extent, determine game quality of each individual. Related to this, situational-motor skills that are a combination of motor and functional abilities with technical-tactical knowledge, are some kind of precondition for solving situations created in the game. So, reparation in the field of motor and functional abilities, technical-tactical knowledge, psychic (conative and cognitive) factors, but also the factor of sports luck, Are of utmost importance for success in sports as well as in volleyball. Diagnostics of the coordination structure began in the early 1980's (Hošek, 1976, Hošek-Momirović, 1981), continued and it lasts until today (Šimonek, 2006; Moriss, 2008; Bokan, 2009; Brodani \& Šimonek, 2010; 2013; 2014; Gongey \& Kerketta, 2016). Each new knowledge confirms an attribute of complex motor skills, and for that reason must be one of the indispensable motor skills that must find in each equation of the specification ${ }^{2}$ of each sport. The breadth and veriety of the coordinative abilities prove its subdivision, so that, in the professional and scientific litetrature can find and forms like speed coordination (the ability to precisely

\footnotetext{
${ }^{2}$ Multidimensionality of which depends the success of the game, hypothetically, is possible to actually write it down in the form of linear equations (Elsner, 1990): $\mathbf{U}=\mathbf{A k 1 + M k 2 + F k 3 + M i k 4 + I k 5 + K k 6 + S k 7 + Z s k 8 + Z f k 9 + P T k 1 0 + . . . ~}$ Ekn. U-success in a volleyball game, $\mathbf{K 1}, \mathbf{k 2}, \ldots, \mathbf{k n}$ - coefficient of influence of the associated factors (weights), Aanthropometric characteristics of the volleyball player, M-motor skills of the volleyball player, F-functional abilities of the volleyball player, Mi-motor skills of volleyball player, I - the intellectual (cognitive) ability of the volleyball player, the K-conative characteristics of the volleyball player, the S-, the Zs-health of the volleyball player, the $\mathbf{Z f}$ influence of external factors (on the competition), the PT-training training course, the E-error). The success factors in sport are defined hierarchically, which means that at the beginning of a series are the most important factors or dimensions, and finally those that are less important. The equation is hypothetical if to the hierarchical structure of the factors of success has been based on the subjective assessment of their importance (Milanović, 2013).
} 
perform the desired movement in a short time), rhythmic coordination (ability to perform the desired task in a continuous or discontinuous rhythm), fast learning of motor tasks, spatialtemporal orientation (the ability to control more objects in space and time, the need for so-called "peripheral" vision), and timeliness. So, coordination is an indisputable essential motor ability that participates in every movement and so in these tests, but the results require an answer to the question: which latent factors are actually determine the coordination abilities volleyball players in research and thus assumed primacy in the realization of the set tasks?

What can be observed on the basis of the results is a fact that, based on specific coordination, is a significant statistical prediction of performing motor tests. Nearly the same conclusions came from authors of earlier research (Šabotić, 2004; Tahiraj, 2007; Babin, Bavčević \& Vlahović, 2013; Schaal, Ransdell, Simonson \& Gao, 2013; Stojanović, at all. 2014.) However, apart from the fact that coordination has a high birth rate $\left(\mathrm{h}^{2}=0.80\right)$ (Pistotnik, 2003) and established correlations in performance, attention is drawn to the fact that performance, with a higher proportion, really determined to some other unidentified (latent) factors or capabilities of young female volleyball players. In the first place they are expressed a two abilities within coordination which are already to a great extent independent, hese are agility and balance whose interaction has been confirmed by Ortega, Ruiz, Castillo \& Sjostrom (2008) and Pradhan (2016). Except agility and balance, the results of this research have shown that coordination of female volleyball players have an indirect impact on strength, speed, endurance, flexibility and the ability to react fast As its integral parts, which was proved in researchs Kansala (2008), Lidiora \& Ziva (2010) and Gangeya \& Kerkette (2016), exploring, among other things, the success factors in volleyball game.

The significant characteristic of the motor tests of this research is that all the tests involved the manipulation of certain subject/prop. In particular, we are talking about ball. On this type of skills affected: a sense of the shape of the object, sense of its size and weight, elasticity and inertia (Poljšak, 1980). The next factor to be taken into account is the functional nature, and refers to the mobility of the joints, strengthening the muscles that flex the fingers and hands, the forearm during the ball pass and strengthening the muscles that are provided by adding the ball. The ball requires movement, dynamics, skill, agility, precision, speed and intelligence, and sometimes strength (Poljšak, 1980). All these are latent character factors, which can be justified by the high percentage of the total variability in the results for all three tests of the system 
dependent variables. Then, one should remember that one situation in the game never repeated twice in the same way so that volleyballs are forced to react in a very short time, regardless of whether they are at the phase of the attack or defense. From this, as important factors in the realization of tests imposed a simultaneous movement of the ball and body (synchronization), control of the desired direction, movement of the ball and body, and the need for excellent visual perception (Iveković, 2013). Perhaps the clearest answer to the question of correlation latent factors to the performance of tasks and their synergy with manifest abilities (female volleyball players), was given by R. V. Roussev (1998) ${ }^{3}$ :

Picture 1. System of coordinating abilities of athletes (R.V. Rousev, 1998).

\begin{tabular}{|c|c|c|c|c|}
\hline \multicolumn{5}{|c|}{ System of coordinating abilities of athletes } \\
\hline $\begin{array}{l}\text { LEVEL } 1 \\
\text { Ability to regulate } \\
\text { the behavior of } \\
\text { muscle fibers. }\end{array}$ & $\begin{array}{c}\text { LEVEL } 2 \\
\text { Ability to regulate } \\
\text { muscular strain }\end{array}$ & $\begin{array}{c}\text { LEVEL } 3 \\
\text { Ability to regulate } \\
\text { movements of body } \\
\text { parts }\end{array}$ & $\begin{array}{l}\text { LEVEL } 4 \\
\text { Ability to move the } \\
\text { whole body }\end{array}$ & $\begin{array}{c}\text { LEVEL } 5 \\
\text { Ability to regulate } \\
\text { moving objects }\end{array}$ \\
\hline $\begin{array}{l}\text { Regulation of muscle } \\
\text { fibers isometry }\end{array}$ & $\begin{array}{l}\text { Regulation of muscle } \\
\text { fibers isometry }\end{array}$ & $\begin{array}{l}\text { Position control } \\
\text { during contact }\end{array}$ & $\begin{array}{l}\text { Regulation of body } \\
\text { balance }\end{array}$ & $\begin{array}{c}\text { Manual stabilization } \\
\text { regulation }\end{array}$ \\
\hline $\begin{array}{l}\text { regulation of muscule } \\
\text { fibers straining }\end{array}$ & $\begin{array}{c}\text { Regulation of muscle } \\
\text { auxotonia }\end{array}$ & $\begin{array}{l}\text { Kinesthetic motor } \\
\text { control }\end{array}$ & $\begin{array}{l}\text { Body rotation } \\
\text { regulation }\end{array}$ & $\begin{array}{l}\text { Tactile manipulation } \\
\text { regulation }\end{array}$ \\
\hline & & $\begin{array}{l}\text { Time motoric } \\
\text { regulation }\end{array}$ & $\begin{array}{l}\text { Visual regulation of } \\
\text { locomotion }\end{array}$ & $\begin{array}{l}\text { Visual regulation of } \\
\text { manipulation }\end{array}$ \\
\hline \multicolumn{5}{|c|}{$\begin{array}{l}\text { Regulation of motiric } \\
\text { imitation }\end{array}$} \\
\hline & & $\begin{array}{c}\text { Acustuc motoric } \\
\text { regulation }\end{array}$ & & \\
\hline
\end{tabular}

\section{CONCLUSION}

Young volleyballs have shown that their coordinating abilities during the performance of the task Shooting the horizontal target with the "bump" (С̌CHOR) are statistically significant. In the test Shooting the vertcal target with "bump" (ČEVER) significant was two types of coordination, coordination in space and coordination on the volleyballnet, while in the third test, Shooting the target in the horizontal plane from position 2 (ČEPOZ2) was shown as a significant coordination on the volleyball net and the one-handed juggling of the ball through the hoop (ŽONG). Taken into consideration that the significance and complexity of coordination in this and similar transferational research is evident, the first conclusion is that latent factors, which

\footnotetext{
${ }^{3}$ Download from: Ragulj, N. (2004). Kineziologija znanost o pokretu. [PTT]. www. marul.ffst.hr/ nrogulj/predavanje.
} 
have determined the coordination abilities of the young female volleyball players can act independently, but also on each other.

We believe that many agree that volleyball technique, in that sense, requires specific coordination. A large number of technical and tactical elements that are applied in the game and a great variability to use them, volleyball game ranks as sports that require specific coordination. Such formulation of specific coordination was defined, among others, by Bompa $(1985,1999)$. The situational coordination is even more complex than specific and is being upgraded to it. It could be described as the ability of a successful, meaningful and unpredictable motor response in 'conflict' competitive situations (Metikoš, Milanović, Prot, Jukić \& Marković, 2003). So whatever it is, general, specific or situational coordination, the research has shown the essence of this ability: the proper relationship of established latent factors as parts of the whole, that give effective results. If we add preconditions as: close connection with volleyball technique, then the ability to solve complex, unforeseen motor tasks (intelligence), the acquisition of kinesthetic sense, a good estimate of spatial parameters, (systematic training), acquired motor skills (motor experience), and the level of development Other motor skills (speed, strength, endurance, flexibility, etc.), the second conclusion is that coordination is important motor skills and that without it one can not expect efficient performance given the technical and tactical structure in volleyball game. Volleyball is one of the most dynamic sports games with a constant change of typical and atypical situations, which players must quickly observe, analyze and adequately respond to them. Related to this, in the training process should strive as much as possible the approval of motor skills necessary for success in volleyball. A higher level of handling with technical-tactical elements, requires a higher level of motor preparation. Only such preparation contributes to a better, easier and economical application of complex movements in competitive conditions. In order to achieve a more efficient performance of the technical activities of the volleyball player, it is necessary a optimal motoric achievemen, respectively, certain "inventories" of acquired motor skills. If these "inventories" of acquired motor skills are larger, above all of the general coordination, thus will be easier to dominate with new movements and the level of development of specific coordination will be higher (Marinković, 2011). All this leads us to the third important conclusion of this research: coordination, no doubt, must have a purpose. It must be functional, that is, should be manifest in order to efficiently realize the set tasks. 


\section{REFERENCES}

Babin, B., Bavčević, T. \& Vlahović, L. (2013). Relations of Motor Abilities and Motor Skills in 11 Year old Pupils. Croatian Journal of Education. 15(2), 251-274.

Bokan, M. (2009). Motoričke sposobnosti odbojkaša i testovi za njihovu procjenu. Fizička kultura, Beograd, 63(1), 116-125.

Bompa, T. O. (1985). Talent identification. Science Periodical on Research andTechnology in Sport, February, 1-11.

Bompa, T. O. (1999). Periodization. Theory and methodology of training (4th ed.). Champaign, (IL): Human Kinetics.

Brodani, J. \& Šimonek, J. (2010). Structure of Coordination Capacities and Prediction of Overall Coordination Performance in Selected Sports. Oradea (HUN): Editura Universitatii din Oradea.

Button, C., Wheat, J. \& Lamb, P. (2014). Why coordination dynamics is relevant for studying sport performance. In K. Davids, R. Hristovski, D. Araújo, N. B. Serre, C. Button, \& P. Passos (Eds.), Complex Systems in Sport (pp. 44-62). New York (USA): Routledge. Company. PMid:25277366

Drabik, J. (1996). Children and Sports Training. Island Point, (VT): Stadion Publishing.

PMid:8699052

Elsner, B. (1990). Nogomet. Ljubljana (RS): Fakultet za telesno kulturo.

Gangey, O. \& Kerketta. I. (2016). Relationship between selected motor fitness and playing ability of volleyball players. International Journal of Academic Research and Development. ISSN: 24554197, Impact Factor: RJIF 5.22; 25-26. Rohini, Delhi, India.

Hošek, A. (1976.) Struktura koordinacije. Kineziologija, 6, 1-2.

Hošek, A. (1981). Povezanost morfoloških taksona s manifestnim i latentnim dimenzijama koordinacije. Kineziologija, 11(4).

Idrizović, K. (2011). Što je to koordinacija? U: Jukić I., Gregov C., Šalaj S., Milanović L., i sur. ur. Trening koordinacije, (pp. 28-41). Zagreb (RH): Kineziološki fakultet. Sveučilište u Zagrebu,

Iveković, I. (2013). Utjecaj motoričkog planiranja, koordinacije i sukcesivnih sposobnosti na motorièki razvoj i društveno ponašanje djece s teškoćama u razvoju. Hrvat. Športskomedicinski Vjesnik. 28, 99-107.

Kansal, D.K. (2008). Applied Measurements Evaluation and Sports selection. SSS Publication New Delhi.

Karalić, T. (2010). Preciznost kao faktor uspješnosti u tehničko-taktičkim strukturama odbojke (Precision as a factor of success in technical and tactical structures of volleyball). Unpublished doctoral dissertation. Istočno Sarajevo: Faculty of Physical Education and Sport.

Karamatić, L. P., Vuljanić, A. \& Peršun, J. (2011). Razvoj koordinacije kod djeteta sportaša. U: Jukić I., Gregov C., Šalaj S., Milanović L. i sur. ur. Trening koordinacije (pp 470-3), Zagreb, (RH): Kineziološki fakultet Sveuèilišta u Zagrebu.

Lidor, R. \& Ziv, G. (2010). Physical and physiological attribute of female volleyball players: A review. Journal of Strength and Conditioning Research. 24(7), 1963-1973.

https://doi.org/10.1519/JSC.0b013e3181ddf835

PMid:20543736

Macner, I. (2011). Koordinacija kao preduvjet razvoju kondicijskih sposobnosti te usvajanju sportskih tehnika. U: Jukiæ I., Gregov C., Šalaj S., Milanović L., i sur. ur. Trening koordinacije, (pp 297300), Zagreb, (RH): Kineziološki fakultet Sveuèilišta u Zagrebu.

Marelić, N., Đurković, T. \& Rešetar, T. (2007). Dijagnostika kondicijskih sposobnosti mlađih dobnih kategorija u odbojci. Godišnja međunarodna konferencija Kondicijska priprema sportaša, (pp 277282), Zagreb, (RH): Kineziološki fakultet. 
Marinković, D. (2011). Trening koordinacije u košarci. Kondicijska priprema sportaša 2011 - Trening koordinacije. Kineziološli fakultet Sveučilišta u Zagrebu, Udruga kondicijskih trenera Hrvatske. Zagreb.

Metikoš, D., Milanović, D., Prot, F., Jukić, I. \& Marković, G. (2003). Teorethical and metodical basics of coordination development. In D. Milanović, I. Jukić (Eds.). Strength and conditioning preparation in sport. Proceedings book of International scientific conference. (pp. 264-270). Zagreb, (RH): Faculty of Kinology Univerity of Zagreb. Sport assosiation of Zagreb.

Milanović, D. (2013). Teorija treninga. Zagreb (RH): Kineziološki fakultet Sveučilišta u Zagrebu.

Milanović, D., Šalaj, S. \& Gregov, C. (2012). Opća kondicijska priprema u funkciji zaštite zdravlja sportaša. Arhiv za higijenu rada i toksikologiju, 63, Suppl. 3, 103-119.

Morris, S. B. (2008). Estimating effect sizes from pretest-posttest-control group designs. Organizational Research Methods, 11(2), 364-386.

https://doi.org/10.1177/1094428106291059

Njaradi, N. (2011). Koordinacija - obilježje pobjednika. U: Jukić I., Gregov C., Šalaj S., Milanović L., i sur. ur. Trening koordinacije, (pp 83-87), Zagreb (RH): Kineziološki fakultet Sveušilišta u Zagrebu.

Ortega, F.B., Ruiz, J.R., Castillo, M.J. \& Sjostrom, M. (2008). Physical fitness in childhood and adolescence: A powerful marker of health. International Journal of Obesity. 32(1):1-11.

https://doi.org/10.1038/sj.ijo.0803774

PMid:18043605

Pion, J., Fransen, J., Deprez, D., Segers V., Vaeyens, R., Philippaerts, R. \& Lenoir, M. (2015). Stature and Jumping Height Are Required in Female Volleyball, but Motor Coordination Is a Key Factor for Future Elite Success. Journal of Strength \& Conditioning Research; Volume 29- Issue 6 -p 1480-1485. https://doi.org/10.1519/jsc.0000000000000778

Pistotnik, B. (2003). Osnove gibanja: gibalne sposobnosti in osnovna sredstva za njihov razvoj v športni praksi. Ljubljana $(\mathrm{RH})$ : Fakulteta za šport, Inštitut za šport.

Poljšak, S. L. (1980). Od loptice do pušbola: vežbe i igre loptama u slici i reči. Beograd, (RS).

Pradhan, K. (2016). Performance indicators of inter university volleyball players in terms of their playing positions. Scientific Culture in Physical Education \& Sports, Twentyfirst Century Publications, Patiala. 651-656.

Schaal, M., Ransdell, L. B., Simonson, S. R., \& Gao, Y. (2013). Physiologic performance test differences in female volleyball athletes by competition level and player position. Journal of Strength and Conditioning Research, 27(7), 1841-1850. https://doi.org/10.1519/JSC.0b013e31827361c4

Stein, T., Simonidis, C., Seemann, W. \& Schwameder, H. (2010). A computational model of human movement coordination. Ed.: R. Dillmann. Advances in Artificial Intelligence. Proceedings of the 33rd Annual German Conference on AI, Karlsruhe, (pp 23-32), Berlin, (D): Springer. https://doi.org/10.1007/978-3-642-16111-7_2

Stojanović, N., Stojanović, T., Stojanović, D., Herodek, K. \& Jurko, D. (2014). Uticaj koordinacionih sposobnosti na preciznost dodavanja lopte “čekićem" u odbojci. Defendologija, 35, 73-81. https://doi.org/10.7251/defsr1401003s

Strahonja, A. \& Janković, V. (1988). Metrijske karakteristike testova za procjenu faktora preciznosti ciljanjem. (Metrical characteristics of tests for the assessment of targeting precision factors). Kineziologija, 20 (1).

Strahonja, A., Janković, V. \& Šnajder, V. (1982). Analiza pouzdanosti i faktorske valjanosti situacionomotoričkih testova $u$ odbojci. (Analysis of the reliability and factorial validity of situational-motoric tests in volleyball). Kineziologija, 14(5), 161-175.

Šabotić, B. (2004). Relacije nekih antropoloških karakteristika sa situaciono-motoričkim sposobnostima u sportskim igrama kod učenika prvog razreda srednjih škola. Niš (RS): Fakultet fizičke kulture, doktorska disertacija. 
Šimonek, J. (1998). Hodnotenie a rozvoj koordinačných schopností 10-17 ročných chlapcov a dievčat [The assessment and development of coordination abilities of 10-17 years old boys and girls]. Nitra (SL): Univerzita Konštantína Filozofa v Nitre.

Šimonek, J. (2006). Model of development of coordination abilities in the long-term sport preparation in volleyball. Oradea, (HUN): Editura Universitaii din Oradea.

Šimonek, J. (2009). Model rozvoja koordinačných schopnostív dlhodobej športovej príprav v športových hrách. Bratislava (SL): PEEM.

Šimonek, J. (2014). Coordination abilities in Volleyball. Warszaw/Berlin: DeGruyter. ISBN 978-837656-083-0; https://doi.org/10.2478/9783110370317

Šimonek, J. (2016). The effect of intervention on the changes of coordination factors in the youth sports preparation. Sport Science 9(2), 77-81.

Tahiraj, E. (2007). Antropometriske i motoričke karakteristike vrhunskih odbojkaša u svetu. Magistarski rad, Pristina, (SR).

Tomljanović M., Krespi, M. \& Bešlija, T. (2011). Integralni trening koordinacije u rukometu. U: Jukić I., Gregov C., Šalaj S., Milanović L., i sur. ur. Trening koordinacije, (pp1366-136), Zagreb, (RH): Kineziološki fakultet Sveučilišta u Zagrebu.

Urgesi, C., Savonitto, M.M., Fabbro, F. i Aglioti, S.M. (2012). Long- and short-term plastic modeling of action prediction abilities in volleyball. Psychol Res. 76, 542-560.

https://doi.org/10.1007/s00426-011-0383-y

PMid:22045443

Verstegen, M. \& Marcello, B. (2001). Agility and Coordination. In: High Performance Sports Conditioning. B. Foran, ed. Champaign: Human Kinetics.

PMCid:PMC113934

Vučetić, V., Sukreški M., Zuber, D. \& Sporiš, G. (2011). Dijagnostički postupci za procjenu razine koordinacije sportaša. U: Jukić I., Gregov C., Šalaj S., Milanović L., i sur. ur. Trening koordinacije, (pp42-49), Zagreb (RH), Kineziološki fakultet Sveučilišta u Zagrebu.

Yasumitsu, T. \& Nogawa, H. (2013). Effects of a Shor-Term Coordination Exercise Program During School Recess: Agility of Seven to Eight Year Old Elementary school children. Perceptual \& Motor Skills, 116(2), 598-610.

https://doi.org/10.2466/25.10.PMS.116.2.598-610

PMid:24032333

Received: 06.06.2017.

Accepted: 25.06.2017.

Correspondence author:

Prof. dr Tamara Karalić

Univerzitet u Banjoj Luci

Fakultet fizičkog vaspitanja i sporta

Katedra sportskih igara

Bulevar vojvode Petra Bojovića la

78000 Banja Luka, Republika Srpska /BiH

Tel: +38766 541309

E-mail: tamara.karalic@ffus.unibl.org 